\title{
Study of Various Morphological Types of Anaemia in Patients With rheumatoid Arthritis and Comparison of Serum Ferritin with Bonemarrow Iron Stores in These Patients.
}

\author{
Dilip M Pancholi', Shyam N Shah ${ }^{2}$, Ketul Joshi ${ }^{3}$ \\ ${ }^{1}$ Assosiate Professor, Department Of Medicine, C. U. Shah Medical College, Gujarat, India, ${ }^{2}$ Senior Resident ,Department Of Medicine, C. U. Shah Medical College, \\ Gujarat, India, ${ }^{3}$ Junior Resident, Department Of Medicine, C. U. Shah Medical College, Gujarat, India.
}

\section{Abstract}

Background: Anemia is a common extra-articular manifestation in rheumatoid arthritis patients. Its severity roughly parallels the activity of the disease1-2. Chronic disease and iron deficiency are considered to be the most significant causes of anemia 3-5. Anemia of chronic disease is usually confused with iron deficiency anemia due to the low level of iron in blood in both forms of anemia. Subjects and Methods: This study was conducted in Department Of Medicine, C. U. Shah Medical College, Gujarat, India. 68 total number of population were included in this study. The duration of study was over a period of six month. Results: In our study, 68 total numbers of cases were included. Among all cases $58.8 \%$ were male \& $41.2 \%$ were female. In the present study, $41.2 \%$ cases were belongs to $31-40$ age group followed by 41 $50(35.2 \%),<30(11.7 \%) \&>50(11.7 \%)$ age group. This study suggested type of anemia which was found $76.5 \%$ Normocytic Normochromic followed by Microcytic Hypochromic 23.5\%. Conclusion: Therefore, it can be concluded from the present study that normocytic normochromic anemia is the most common morphological type of anemia in patients with rheumatoid arthritis. And there is a positive correlation between serum ferritin and BMIS in RA patients presenting with anemia. The results of this study also revealed that serum ferritin is an useful index of iron stores in rheumatoid arthritis.

Keywords: Serum Ferritin, Rheumatoid Arthritis, Bone Marrow Iron Store.

Corresponding Author: Dr. Shyam N Shah, Senior Resident, Department Of Medicine, C. U. Shah Medical College, Gujarat, India.

Received: August 2019

Accepted: September 2019

\section{Introduction}

Anemia is a common extra-articular manifestation in rheumatoid arthritis patients. Its severity roughly parallels the activity of the disease. ${ }^{[1-2]}$ Chronic disease and iron deficiency are considered to be the most significant causes of anemia. ${ }^{[3-5]}$ Anemia of chronic disease is usually confused with iron deficiency anemia due to the low level of iron in blood in both forms of anemia.Circulation of iron in blood is necessary for RBC production. Iron deficiency anemia means depletion of stored iron in the body's tissues. Whereas, in chronic disease anemia, iron stores in bone marrow are normal or high. Though, normal iron stores in bone marrow, yet there is low level of iron occurs in anemia of chronic disease. The reason behind this is that inflammatory and chronic diseases interfere with the body's ability to use stored iron and absorb iron from the diet. In rheumatoid arthritis patients, anemia of chronic disease is part of a hematological stress syndrome. It is induced by the release of several cytokines in response to cellular injury caused by inflammation. Cytokines could cause excessive macrophage sequestration of iron and iron binding protein, increased splenic destruction of red cells, and suppressed erythropoietin production in the kidneys and action in the marrow. Anemia is normocytic normochromic in $60 \%$ to $70 \%$ and microcytic hypochromic in $30 \%$ to $40 \%$ of cases in anemia of chronic disease. ${ }^{[6]}$ The useful index of iron stores or of iron deficiency is serum ferritin. Generally, 1 microgram/liter serum ferritin roughly corresponds to about $8 \mathrm{mg}$ of storage iron. But ferritin is also an acute phase protein. Inflammation and infections increase its synthesis and produce high serum levels. Thus, mostly in chronic disease, ferritin is not reliable for estimating bone marrow iron deficiency. Though, for the acute phase response, if we use the correct levels of serum ferritin, we could still use it for estimating of iron stores in bone marrow of patients with anemia of chronic disease. ${ }^{[7]}$ The aim of this study was to study the various morphological types of anemia in patients with rheumatoid arthritis and also to correlate serum ferritin with bone marrow iron stores (BMIS) in patients with rheumatoid arthritis.

\section{Subjects and Methods}

\section{Study Area}

This study was conducted in Department Of Medicine, C. 


\section{U. Shah Medical College, and Gujarat, India.}

\section{Study Population}

68 total number of population were included in this study.

\section{Study Duration}

The duration of study was over a period of six month.

\section{Sample Collection}

Patients who presented with anaemia and suffering from RA were taken up for the study. Blood samples and bone marrow aspiration were done after taking consent. History and clinical details of the patients was recorded. Haemoglobin Estimation was done using the automated cell counter cynmethaemoglobin method.

\section{Peripheral Blood Film}

It was stained using Leishmans stain. Red cell indices comprising of mean corpuscular volume (MCV), mean corpuscular haemoglobin $(\mathrm{MCH})$, mean corpuscular haemoglobin concentration (MCHC) were estimated using automated cell counter. Bone marrow aspiration was done from posterior superior iliac spine under complete aseptic conditions using Salah's aspiration needle. Smears were stained with Leishman/Giemsa stain for assessment of cellularity and morphological details. Perls' Prussian blue staining was done on one slide for estimation for estimation of marrow iron stores.

\section{Data Analysis}

Data were analyzed by using Microsoft excel.

\section{Results}

In our study, 68 total numbers of cases were included. Among all cases $58.8 \%$ were male \& $41.2 \%$ were female. In the present study, $41.2 \%$ cases were belongs to $31-40$ age group followed by 41-50(35.2\%), <30 (11.7\%) \&>50 $(11.7 \%)$ age group. This study suggested type of anemia which was found $76.5 \%$ Normocytic Normochromic followed by Microcytic Hypochromic 23.5\%.Mean of RBCs indices showed in table no. 5. Our study found that $55.8 \%$ cases had $9-9.9 \mathrm{gm} / \mathrm{dl} \mathrm{Hb}$ followed by $8-8.9 \&>10$. $85.3 \%$ cases had normal or increased \& $14.7 \%$ decreased bone marrow iron storage. Grading of bone marrow iron storage showed in table 7.

Table 1: Distribution of Cases According to Gender.

\begin{tabular}{|l|l|l|}
\hline Gender & No. Of Cases & Percentage \\
\hline Male & 28 & $41.2 \%$ \\
\hline Female & 40 & $58.8 \%$ \\
\hline Total & 68 & $100 \%$ \\
\hline
\end{tabular}

Table 2: Distribution of Cases According to Age.

\begin{tabular}{|l|l|l|}
\hline Age & No. of Cases & Percentage \\
\hline$<30$ & 8 & $11.7 \%$ \\
\hline $31-40$ & 28 & $41.2 \%$ \\
\hline $41-50$ & 24 & $35.2 \%$ \\
\hline$>50$ & 8 & $11.7 \%$ \\
\hline Total & 68 & $100 \%$ \\
\hline
\end{tabular}

Table 3: Distribution of Cases According To Anemia.

\begin{tabular}{|l|l|l|}
\hline Type of Anemia & No. Of Cases & Percentage \\
\hline Normocytic Normochromic & 52 & $76.5 \%$ \\
\hline Microcytic Hypochromic & 16 & $23.5 \%$ \\
\hline Macrocytic Normochromic & 0 & $0 \%$ \\
\hline Dimorphic Anemia & 0 & $0 \%$ \\
\hline Total & 68 & $100 \%$ \\
\hline
\end{tabular}

Table 4: Distribution of Cases According To Mean of Indices

\begin{tabular}{|l|l|}
\hline Indices & Mean \\
\hline MCV(fl.) & 85.1 \\
\hline MCH(pg.) & 28.5 \\
\hline MCHC(gm/dl) & 32.9 \\
\hline
\end{tabular}

Table 5: Distribution of Cases According To $\mathrm{Hb}$

\begin{tabular}{|l|l|l|}
\hline Hb $(\mathbf{G m} / \mathbf{D I})$ & No. Of Cases & Percentage \\
\hline $8-8.9$ & 18 & $26.4 \%$ \\
\hline $9-9.9$ & 38 & $55.8 \%$ \\
\hline$>10$ & 12 & $17.6 \%$ \\
\hline TOTAL & 68 & $100 \%$ \\
\hline
\end{tabular}

Table 6: Distribution of Cases According To Bone Marrow Storage.

\begin{tabular}{|l|l|l|}
\hline Bone marrow iron stores grade & No. Of Cases & Percentage \\
\hline DECREASED & 10 & $14.7 \%$ \\
\hline Normal Or Increased & 58 & $85.3 \%$ \\
\hline Total & 68 & $100 \%$ \\
\hline
\end{tabular}

Table 7: Distribution of Cases According To Grading Of Bone Marrow Iron Storage.

\begin{tabular}{|l|l|l|}
\hline $\begin{array}{l}\text { Grading Of Bone Marrow Iron } \\
\text { Storage }\end{array}$ & No. Of Cases & Percentage \\
\hline Grade 0 & 8 & $11.7 \%$ \\
\hline Grade1 & 2 & $2.9 \%$ \\
\hline Grade2 & 12 & $17.6 \%$ \\
\hline Grade3 & 12 & $17.6 \%$ \\
\hline Grade4 & 10 & $14.7 \%$ \\
\hline Grade5 & 16 & $23.5 \%$ \\
\hline Grade6 & 8 & $11.7 \%$ \\
\hline TOTAL & 68 & $100 \%$ \\
\hline
\end{tabular}

\section{Discussion}

This study was carried out in post graduate department of pathology, Acharya Shri Chander College of Medical Sciences and Hospital Sidhra, Jammu over a period of one year. 34 patients of rheumatoid arthritis presenting with anemia were studied in the present study. The results of this study showed that normocytic normochromic anaemia was most common morphological type of anemia. It was found in $76.5 \%$ of patients followed in frequency by microcytic hypochromic in $23.5 \%$ patients. Similar findings were found in study by Vreugdenhil et al 1994. They evaluated erythrocyte and serological parameters in 44 anemic rheumatoid arthritis patients and found out that the anemia was $60 \%$ in normocytic normochromic and $30 \%$ in hypochromic normocytic patients. In normal subjects, serum ferritin concentration correlates well with iron stores. In this study, the relationship of serum ferritin concentration indicates a similar association with body stores.

This also observed a positive correlation between serum ferritin and BMIS (0.539; $\mathrm{p}=0.001)$ in all 34 rheumatoid 
arthritis patients. These findings are supported by the study of Porter et al in $1994^{[8]}$.

They observed 101 patients of rheumatoid arthritis with anemia. They found that $93 \%$ of patients with ferritin $<50 \mathrm{ng} / \mathrm{ml}$ were iron deficient on bone marrow examination and $91 \%$ of patients with ferritin $>100 \mathrm{ng} / \mathrm{ml}$ were iron replete on bone marrow examination. Shroff et al $1991^{[9]}$ revealed that there was a strong positive correlation between serum ferritin levels and marrow iron stores ( $\mathrm{r}$ $=+0.08, \mathrm{p}<0.001)$ in 30 rheumatoid arthritis patients. Palermo et al $1986^{[10]}$ assessed bone marrow aspirate from the sternum of 40 patients with rheumatoid arthritis with anemia. They showed that in these patients serum ferritin correlated with other indices of iron stores and disease activity.

\section{Conclusion}

Therefore, it can be concluded from the present study that normocytic normochromic anemia is the most common morphological type of anemia in patients with rheumatoid arthritis. And there is a positive correlation between serum ferritin and BMIS in RA patients presenting with anemia. The results of this study also revealed that serum ferritin is an useful index of iron stores in rheumatoid arthritis. Higher than expected values of serum ferritin may be found in active disease. If corrected for the acute phase response, serum ferritin concentrations could be used to estimate the iron stores in patients of rheumatoid arthritis.

\section{References}

1. Nilsson, F. (1948). Anaemia problems in rheumatoid arthritis.ActaMedicaScandinavica, 130(Suppl. 210).

2. JEFFREY, M. R. (1953). Some Observations on Anemia in Rheumatoid Arthritis.Blood, 8(6), 502-518.

3. Hansen N E. (1983). The anaemia of chronic disorders: a bag of unsolved questions. Scand J Haematol, 31: 397-402.

4. Vreugdenhil, G., Wognum, A. W., Van Eijk, H. G., \&Swaak, A. J. (1990). Anaemia inrheumatoid arthritis: the role of iron, vitamin B12, and folic acid de $\square$ ciency, and erythropoietin responsiveness. Annals of the Rheumatic Diseases, 49(2), 93-98.

5. Baer, A. N., Dessypris, E. N., \&Krantz, S. B. (1990, February). The pathogenesis of anemia in rheumatoid arthritis: a clinical and laboratory analysis. In Seminars in arthritis and rheumatism (Vol. 19, No. 4, pp. 209-223). WB Saunders.

6. WiansJr, F. H., Urban, J. E., Keffer, J. H., \&Kroft, S. H. (2001). Discriminating between iron de $\square$ ciency anemia and anemia of chronic disease using traditional indices of iron status vs transferrin receptor concentration.American journal of clinical pathology, 115(1), 112-118.

7. Witte, D. L., Dick, F., Goeken, J., Johnson, G., \& Pennell, B. (1985, January). C-reactive protein (CRP) aids interpretation of serum ferritin (FRTN). In Clinical Chemistry (Vol. 31, No. 6, pp. 10111011). 2101 L STREET NW, SUITE 202, WASHINGTON, DC 20037-1526: AMER ASSOC CLINICAL CHEMISTRY.

8. Porter, D. R., Sturrock, R. D., \&Capell, H. A. (1994). The use of serum ferritin estimation in the investigation of anaemia in patients with rheumatoid arthritis.Clinical and experimental rheumatology, 12(2), 179-182

9. Shroff, K., Gaiha, M., Singh, T., \& Sharma, S. K. (1991). Iron status in patients of rheumatoid arthritis with special reference to serum ferritin levels. The Journal of the Association of Physicians of India, 39(9), 675-677.

10. Palermo, C., Bongi, S. M., \&Bianucci, G. (1986). Relationship between serum ferritin, iron stores and disease activity in rheumatoid arthritis. International Journal of Clinical \& Laboratory Research, 16(3), 463-469.

Copyright: () the author(s), 2019. It is an open-access article distributed under the terms of the Creative Commons Attribution License (CC BY 4.0), which permits authors to retain ownership of the copyright for their content, and allow anyone to download, reuse, reprint, modify, distribute and/or copy the content as long as the original authors and source are cited.

How to cite this article: Panchol DM, Shah SN, Joshi K. Study of Various Morphological Types of Anaemia in Patients With rheumatoid Arthritis and Comparison of Serum Ferritin with Bonemarrow Iron Stores in These Patients. Asian J. Med. Res. 2019;8(3):ME20-ME22. DOI: dx.doi.org/10.21276/ajmr.2019.8.3.ME7 